\title{
Efficacy of Trichogramma chilonis in comparison with a seed dresser (Confidor) against Maize stem Borer (Chilo Partellus Swinhoe)
}

\author{
Muhammad Qasim Kakar ${ }^{1 *}$, Arif Shah ${ }^{1}$, Farman Ullah ${ }^{2}$, Hayat \\ Badshah $^{2}$, Hayat Zada ${ }^{2}$, Bashir Ahmad ${ }^{2}$ and Toheed Iqbal ${ }^{3}$ \\ 1. Department of Agriculture Extension, Agriculture \& Cooperatives Department Balochistan-Pakistan \\ 2. Department of Plant Protection, The University of Agriculture Peshawar-Pakistan \\ 3. Department of Entomology, The University of Agriculture Peshawar-Pakistan \\ *Corresponding author's email: qasimkakar@aup.edu.pk
}

Citation

Muhammad Qasim Kakar, Arif Shah, Farman Ullah, Hayat Badshah, Hayat Zada, Bashir Ahmad and Toheed Iqbal. Efficacy of Trichogramma chilonis in comparison with a seed dresser (Confidor) against Maize Stem Borer (Chilo Partellus Swinhoe). Pure and Applied Biology. Vol. 5, Issue 3, pp664-670. http://dx.doi.org/10.19045/bspab.2016.50086

\begin{tabular}{|c|c|c|c|}
\hline Received: 26/05/2016 & Revised: 02/06/2016 & Accepted: 08/06/2016 & Online First: 11/06/2016 \\
\hline
\end{tabular}

\section{Abstract}

The present research was initiated with the objective to evaluate the efficacy of $T$. chilonis at different release levels in comparison with confidor (immidacloprid) 70WS during the year 2006. The experiment was laid out in RCB design with five treatments including untreated check each replicated four times. Treatments applied consisted of: seed dresser immidacloprid single release 10 trichocards per level (dose), double release 20 cards per level and triple release 30 cards per level and untreated check. Results revealed that both infestation (\%) of the borer and egg parasitism is significantly influenced by the releases of $T$ chilonis at different levels as compared to immidacloprid treated plots and check. The triple releases resulted in better parasitism, followed by double releases, whereas immidacloprid was the lowest in parasitism. Minimum infestation (overall \%) was recorded in the treatment where 30 trichocard, were used whereas maximum infestation (overall \%) was observed in control plots. The highest grain yield was recorded in the triple released plots followed by double released and imidacloprid and single released plots, low yield was recorded in control plots. Triple releases of trichocards resulted in maximum parasitism and lowest infestation of stem borers and hence recommended for better and environmental friendly management of stem borers in maize crop.

Key words: Levels; Confidor; Immidacloprid.

\section{Introduction}

Maize (Zea mays, L.) is an important cereal crop of Pakistan. During 2010-11 the total area under maize cultivation was 974.2 thousand hectares with a total production of 3707.0 thousands tones. In Khyber Pakhtunkhwa, total area and production was 422.9 thousand hectares and 740.5 thousand million tonns, respectively [1] during the same year. Maize production is severely affected by number of biotic and abiotic factors. Among biotic factors stem borer (Chilo partellus Swinhoe) is the most notorious and destructive pest [2]. Stem borer appears in March and remain active till 
November and passes the winter as fullgrown larvae in the stubbles [3].

Because of pesticides use, problems have increased, thus it has stimulated renewed interest in biological control as a control method by itself or as a part of integrated pest control system. Among biological techniques, inundative releases of Trichogramma spp. have led to commercially successful programs against Ostrinia nubilalis [4]. In areas where Trichogramma spp. have been released continuously for years, has resulted in large ecological and economic benefits [5]. Trichogramma spp. is a tiny (5mm long) parasitoid, which attacks the eggs of its host. As a biological control agent, $T$. chilonis wasp are reared and released in the affected fields [6]. The larva ( $T$. evanescens) goes through three developmental stages and pupate inside the host egg that cause host eggs turn black [7].

Trichogramma species have been reported from various hosts i.e, Acigona steniellus, Helicoverpa armigera, Chilo partellus, Chilo infuscatellus, and Emmalocera depressella [8]. Parasitization percentage of $T$. chilonis against tomato fruit borer increased with increasing tricocard number [9].

The present research was therefore initiated to study the efficacy of $T$. chilonis at different release levels in comparison with imidacloprid a seed dresser against maize stem borer (C. partellus).

\section{Materials and methods}

The study was conducted at Malakandhar Farm The University of Agriculture, Peshawar. Maize variety Azam was sown in $300 \mathrm{~m}^{2}$ area, which were sub divided into 20 experimental units having plot size $4.2 \times 3.6 \mathrm{~m}^{2}$ consisting of six rows. Row to row distance was $70 \mathrm{~cm}$ whereas plant to plant distance was $20 \mathrm{~cm}$. There were five treatments viz. $\mathrm{T}_{1}$ (control), $\mathrm{T}_{2}$ (Seed dresser /immidacloprid), $\mathrm{T}_{3}$ (single release of 10 Tricho cards (each card having 450 eggs of Sitotroga cereallela parasitized by T. chilonis), $\mathrm{T}_{4}$ (double release 20 cards) and $\mathrm{T}_{5}$ triple release 30 cards were applied to the experimental units. The treatments were replicated four times with buffer zones of $200 \mathrm{~m}^{2}$. All these releases were made at fifteen days interval where first release ( 0 days release) was made on $20^{\text {th }}$ May, $2^{\text {nd }}$ on $5^{\text {th }}$ June and $3^{\text {rd }}$ was on $20^{\text {th }}$ June. These plots were regularly monitored at 7 days intervals and the data were collected after the 7 days of 0 days release in each plot respectively and the data were summed up for a month interval. Egg batches of $C$. partellus were randomly collected from maize fields.

The culture of $S$. cerealella was maintained in the Plant Protection laboratory The University of Agriculture, Peshawar. T. chilonis parasitized cards (size $4 \mathrm{~cm}^{2}$ ), from which adult were ready to emerge in 24 hours were stapled to the maize leaves according to the treatments i.e. single release where 10 cards were tagged at 0-days interval, 20-cards in double release at 10 cards at 0 day and 20 days interval and in triple release plot 30 cards were released at 10 cards/plot at 0 , 20 and 35 days interval respectively and control plots were kept untreated. The cards were attached randomly by an ordinary stapler in the field at 5 different places in each plot to the maize leaves in each plot when the pest population reached upto economic threshold level.

The data were recorded at one-meter $(\mathrm{m})$ long row from each plot and were examined for borer eggs at 7 days interval. Data of percent parasitism and percent infestation were recorded on weekly basis. Number of infested plants per plot and number parasitized eggs were converted into percentage. Following maturity of crop, the yield components, viz., grain per $\operatorname{cob}(20$ cobs at random), thousands grain weight, grain yield $\mathrm{kg}^{-1 \mathrm{ha}}$ and biological yield $\mathrm{kg}$ 1ha were recorded by selecting 20 plants from each plot randomly The leaves with eggs batch of $C$. partellus were cut in size of $5 \mathrm{~cm}$ from the maize and were kept in the Petri dish with moist tissue paper and kept in the laboratory for 
proper emergence of the parasitoid $T$. chilonis if any and then the percent parasitism was calculated.

\section{Statistical analysis}

The data were statistically analyzed through 2-way ANOVA in MSTAT C package (Michigan State University, 1991), and means for different parameters were separated by applying least significant difference (LSD) test at $0.05 \%$ level of probability to know their significance status, [10] followed the procedure as applied by [11].

\section{Results and discussion Percent parasitism}

Release of $T$. chilonis at different intervals significantly influenced its percent parasitism as compared to control and imidacloprid treated plots. Tricocard level/number per unit area significantly affects percent parasitism, maximum parasitism $(32.82 \%)$ of $C$. partellus was observed in plot treated with triple (30 cards/plot) release followed by double $(26.20 \%)$ and single release $(20.62 \%)$. While, minimum $(7.7 \%)$ parasitism were recorded in plot treated with immidacloprid with with no significant difference from control plot (8.82\%) (table 1 ). Results showed that the releases of $T$. chilonis play a vital role in increasing of percent parasitism of $C$. partellus eggs. The results are in conformity with [12] and [8], who studied the increase in percent parasitism by $T$. chilonis. It seems that the releases of $T$. chilonis worked in bringing down the pest population. There is a need for continuous efforts and cooperative work through the maize growing built and in particular where the pest is a serious problem. The presence of parasitized eggs in the control plots and immidacloprid treated plots shows that the T. chilonis is present in the area naturally during the study. There is a need to monitor population of $T$. chilonis in the target area and further releases should be made accordingly.

\section{Percent infestation (overall)}

Table 1 determines the leaf damage, infested stubbles and dead hearts. Analysis of the data indicated that infestation by $C$. partellus was maximum in control plots (17\%), followed by imidacloprid treated plots $(10.5 \%)$, where as minimum $(5.5 \%)$ infestation was observed in triple release plots. In this case our results again coincide with [12-14], where they worked on effectiveness of $T$. chilonis against sugarcane borer and achieved similar results, besides; this is more environment friendly and carry no health problem. Mean value of the data (Table 1) showed that there is significant difference in the releases of $T$. chilonis at different released levels in the management of maize stem borer. It is apparent that the different releases of $T$. chilonis play an essential role in the reduction of pest infestation. The results are in agreement with findings of [8], who studied the effectiveness of $T$. chilonis and found out the impact of $T$. chilonis in reduction of percent infestation by maize stem borer. The $T$. chilonis releases at different interval were made according to the phenology of $C$. partellus and releases were made on the appearance of the adult of stem borer in the fields of maize which leads to synchronization of the egg parasitoid to the host C. partellus. Our results are fully supported by the findings of $[8,15]$, which investigated that T. chilonis effectively control sugar cane stem borer. However, in contrast to our results [16], reported that $T$. chilonis being ineffective against the maize stem borer, may be this situation could be due to abnormal environmental conditions where Trichogramma can't reproduce effectively that could be sufficient for borer eggs parasitism. 
Table 1. Efficacy of Trichogramma chilonis (ishii) in comparison with seed dresser/immidacloprid) against the maize stem borer (Chilo partellus Swinhoe)

\begin{tabular}{|l|c|c|c|c|c|}
\hline Treatments & $\begin{array}{c}\text { \% leaf } \\
\text { Damage } \\
\mathbf{\pm S D}\end{array}$ & $\begin{array}{c}\text { \% Dead } \\
\text { Hearts } \\
\mathbf{\pm} \text { SD }\end{array}$ & $\begin{array}{c}\text { \% Infested } \\
\text { Stubbles } \\
\mathbf{\pm} \text { SD }\end{array}$ & $\begin{array}{c}\text { \% Infestation } \\
\text { (overall) } \\
\mathbf{\pm} \text { SD }\end{array}$ & $\begin{array}{c}\text { \% } \\
\text { Parasitism } \\
\mathbf{\text { SDD }}\end{array}$ \\
\hline Control & $19.8 \mathrm{a} \pm 4.85$ & $14.88 \mathrm{a} \pm 2.95$ & $15.75 \mathrm{a} \pm 3.95$ & $17.0 \mathrm{a} \pm 1.7$ & $08.82 \mathrm{~d} \pm 1.28$ \\
\hline $\begin{array}{l}\text { immidacloprid } \\
70 \% W S\end{array}$ & $13.47 \mathrm{~b} \pm 3.37$ & $07.75 \mathrm{c} \pm 1.55$ & $10.62 \mathrm{~b} \pm 1.38$ & $10.5 \mathrm{c} \pm 0.5$ & $07.7 \mathrm{~d} \pm 0.56$ \\
\hline Tricho. Level 1 & $\begin{array}{c}16.87 \mathrm{ab} \pm \\
2.95\end{array}$ & $11.62 \mathrm{~b} \pm 2.06$ & $12.42 \mathrm{~b} \pm 1.99$ & $14.0 \mathrm{~b} \pm 0.8$ & $20.62 \mathrm{c} \pm 3.42$ \\
\hline Tricho. Level 2 & $9.37 \mathrm{~cd} \pm 0.85$ & $\begin{array}{c}06.25 \mathrm{~cd} \pm \\
1.04\end{array}$ & $07.87 \mathrm{c} \pm 0.85$ & $08.0 \mathrm{~d} \pm 0.3$ & $26.20 \mathrm{~b} \pm 2.51$ \\
\hline Tricho. Level 3 & $6.75 \mathrm{~d} \pm 0.65$ & $04.05 \mathrm{~d} \pm 0.84$ & $05.9 \mathrm{c} \pm 1.10$ & $05.5 \mathrm{e} \pm 0.5$ & $32.82 \mathrm{a} \pm 3.28$ \\
\hline LSD value & 4.76 & 2.36 & 2.66 & 1.46 & 3.59 \\
\hline
\end{tabular}

Mean in column followed by the same letters are non-significant at $5 \%$ level of probability using LSD test.

Yield

\section{Grain per cob}

Data regarding the yield parameters are presented in Table 2. Analysis of the data showed that statistically significant variation found among the yield component of the treatments. It showed that maximum (447.96 grains/cob) were recorded in plots where 30 tricho cards were tagged, followed by $(369.65$ grains/cob) in the plots where 20 tricho cards were used. While, minimum (289 grains/cob) were obtained in control plot. By comparing chemical treatments with biological treatments it is found that immidacloprid gave the same results as recorded from plots where 20 tricho cards were used per plot and better results than treatments where 10 tricho cards were tagged.

\section{Thousand grain weight (g)}

The results showed that maximum (220 g) thousand grain weight was recorded in plots where 30 tricho cards were tagged, followed by $(209 \mathrm{~g})$ in plots where 20 tricho cards were used. While minimum $(195 \mathrm{~g})$ thousand grain weights was obtained in control plot. By comparing chemical treatment with biological treatments it is found that imidacloprid gave better results with (206.57g) thousand-grain weight than (205.49g) thousand-grain weight from plots where 10 tricho cards were tagged.

\section{Grain yield (kg/ha)}

The data revealed that maximum (3836 $\mathrm{kg} / \mathrm{ha}$ ) grain yield was recorded in plots where 30 tricho cards were used, followed by $(3274 \mathrm{~kg} / \mathrm{ha})$ where 20 tricho cards were used. While minimum $(2611 \mathrm{~kg} / \mathrm{ha})$ grain yield was recorded in control plot. By comparing chemical treatment with biological treatments it is found that imidacloprid give better results with grain yield of $3109 \mathrm{~kg} / \mathrm{ha}$ than $(2742 \mathrm{~kg} / \mathrm{ha})$ where 10 tricho cards were tagged.

\section{Biological yield (kg/ha)}

Statistical analysis of the data indicated that there was significant variation among the different treatments. It revealed that maximum (7306 kg/ha) biological yield was recorded in plots where 30 tricho cards were stapled, followed by $(7251 \mathrm{~kg} /$ ha) in plots where 20 trichocards were used. While minimum $(6808 \mathrm{~kg} / \mathrm{ha})$ was recorded in the untreated control plots. By comparing chemical treatment with biological treatments, table 2 showed that the difference loprid with biological yield of $7032 \mathrm{~kg} / \mathrm{ha}$ and 10 Tricho card treated plots (6979) $\mathrm{kg} / \mathrm{ha}$ was found nonsignificant. Overall, results showed that grain yield of maize increases with the increase of percent parasitism (Figure 1). It is shown that with the increase of percent parasitism (30 to $40 \%$ ), the grain increases (3500-4000 kg/ha).

Results shows that yield components of 
check plots and treated plots were highly significant. It is clear from data that in all treated plots values of yield components were higher compared to control. Similarly, among treated plots values of yield components increased with increasing tricocard per unit area. Overall our result are in agreement with [6] who found that $C$. partellus infestation in maize crop was significantly lower in IPM treatment compared to check plot. In another study [9] reported that Chilo partellus alone caused yield losses of 10$50 \%$ in Peshawar valley.

Table 2. Yield parameters as affected by different treatments (Trichogramma levels) and chemical in comparison with control

\begin{tabular}{|l|c|c|c|c|}
\hline $\begin{array}{c}\text { Treatments } \\
\text { (Trichogramma } \\
\text { levels) }\end{array}$ & $\begin{array}{c}\text { No. of Grains } \\
\text { per Cob }\end{array}$ & $\begin{array}{c}\text { Thousand } \\
\text { Grain } \\
\text { Weight }(\mathbf{g})\end{array}$ & $\begin{array}{c}\text { Grain Yield } \\
\text { (kg/ha) }\end{array}$ & $\begin{array}{c}\text { Biological Yield } \\
\text { (kg/ha) }\end{array}$ \\
\hline Control & $289.000 \mathrm{~d}$ & $195.800 \mathrm{c}$ & $2610.75 \mathrm{~d}$ & $6808.25 \mathrm{~b}$ \\
\hline $\begin{array}{l}\text { Immidacloprid } \\
70 \% W S\end{array}$ & $361.325 \mathrm{~b}$ & $206.568 \mathrm{~b}$ & $3109.25 \mathrm{~b}$ & $7032.25 \mathrm{ab}$ \\
\hline $\begin{array}{l}\text { Trichogramma, } \\
\text { Level 1 }\end{array}$ & $329.325 \mathrm{c}$ & $205.485 \mathrm{bc}$ & $2742.25 \mathrm{c}$ & $6979.50 \mathrm{ab}$ \\
\hline $\begin{array}{l}\text { Trichogramma, } \\
\text { Level 2 }\end{array}$ & $369.650 \mathrm{~b}$ & $209.118 \mathrm{ab}$ & $3273.75 \mathrm{~b}$ & $7251.00 \mathrm{ab}$ \\
\hline $\begin{array}{l}\text { Trichogramma, } \\
\text { Level 3 }\end{array}$ & $447.960 \mathrm{a}$ & $220.300 \mathrm{a}$ & $3836.25 \mathrm{a}$ & $7306.25 \mathrm{a}$ \\
\hline LSD value & 24.03 & 13.68 & 123.1 & 368.29 \\
\hline
\end{tabular}

Means in each column followed by the same letters are not significantly different at $5 \%$ level of probability.

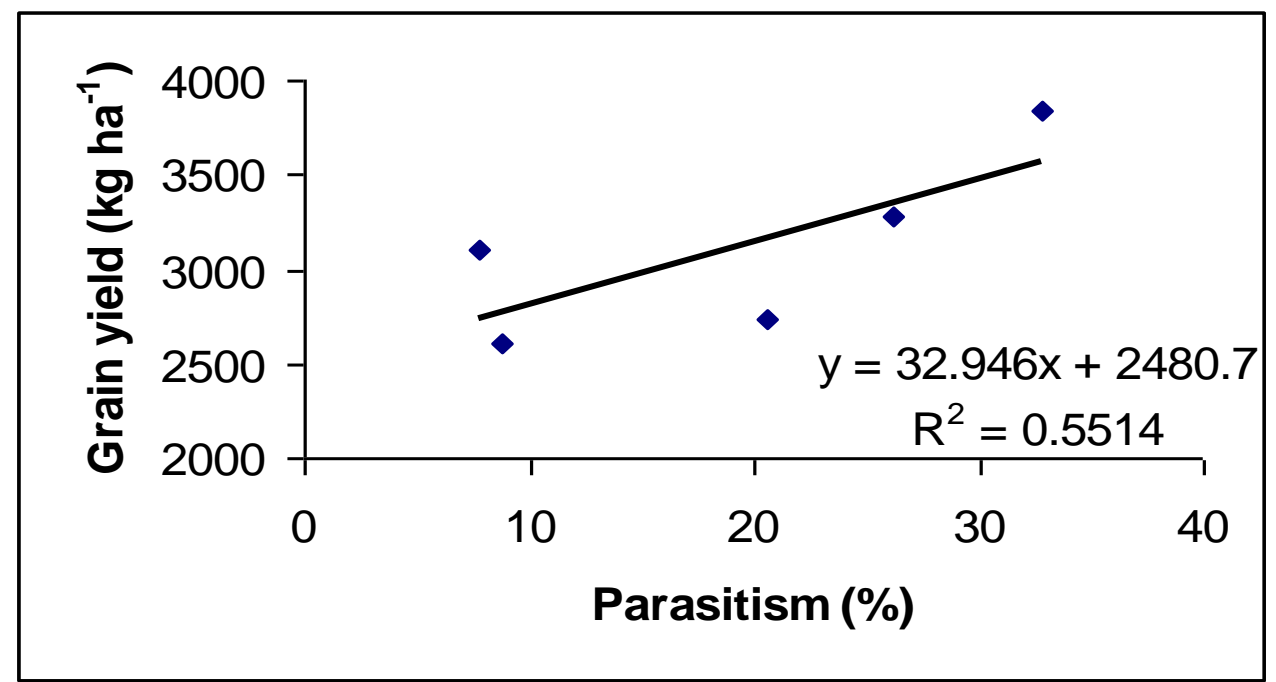

Figure 1. Correlation between percent parasitism of maize stem borer (C. partellus) by T. chilonis ishii and grain yield of maize 


\section{Conclusion and recommendations}

Based on the experiment, it is concluded that trichocard release was the best and environment friendly substitute of the chemical control in managing the deadly maize stem borer. The triple release in comparison to single and double release proved the best reducing the maize stem borer infestation, so triple release of trichocard is recommended.

The phenology of the maize stem borer should be studied before the tagging of trichocards and trichocards should be tagged in the fields after the appearance of the adults of maize stem borer so that Trichogramma should synchronize with the eggs of the pest.

\section{Authors' contribution}

Conceived and designed the experiments: MQ Kakar \& F Ullah, Performed the experiments: MQ Kakar \& T Iqbal, Analyzed the data: A Shah \& H Badashah, Contributed reagents/ materials/ analysis tools: H Zada \& B Ahmad, Wrote the paper MQ Kakar.

\section{Reference}

1. Anonymous (2010-11). Agricultural Statistics of Pakistan. Government of Pakistan, Statistics DivisionPakistan Bureau of Statistics. p18.

2. Songa JM, Guofa Z \& Overholt WA (2001). Relationships of stemborer damage and plant physical conditions to maize yield in a semi-arid zone of eastern Kenya. Int J Trop Insect Sci 21(03): 243-249.

3. Atwal AS \& Dhaliwal GS (2009). Agricultural Pests of South East Asia and Their Management. College of agriculture; Ludhiana, India. Kalyani Publishers, New Delhi. 502 pp.

4. Bigler F (1986). Mass production of Trichogramma maidis Pint, et Voeg. and its field application against Ostrinia nubilalis Hbn. in nd1. J App Entomol 101(1-5): 2329.
5. Ullah F, Shakur M, Badshah H, Ahmad S, Amin M \& Zamin M (2012). Efficacy of Trichogramma chilonis ishii in comparison with two commonly used insecticides against sugarcane stem borer chilo Infuscatellus snellen (lepidoptera: pyralidae). J Anim Plant Sci 22: 463-466.

6. Wan ZY, He K, Zhao JZ \& Zhou DR (2003). Implementation of Integrated Pest Management In China. In "Integrated Pest Management in the Global Arena" (K M. Maredia, D. Dakouo, and D. Mota-Sanchez, Eds.), pp.197-207. CABI Publishing, Oxon.

7. Hassan SA (1981). Mass production and utilization of Trichogramma production of host Sitotroga cerealella. Entomophaga 26 (4): 339-347.

8. Mohyuddin AI (1988). Integrated pest management of the top borer Scirpophoha excerptalis and stem borer Chilo Infuscatellus in Sindh, Pakistan. Proc. 23 $3^{\text {rd }}$ Ann. Conv. Pakistan Society of Sugar Technologist. 108-116.

9. Hussain D, Ali H, Qasim M \& Khan J (2015). Insecticidal Susceptibility and Effectiveness of Trichogramma chilonis as Parasitoids of Tomato Fruit Borer, Helicoverpa armigera. Pak J Zoo 47(5): 14271432.

10. Badshah H, Wajid A, Sattar S, Saeed M \& Anwar S (2011). Testing the toxic effects of six different groups of chemical insecticides against tobacco bud worm Helicoverpa armigera Hub. Lepidoptera: Noctuidae in FCV Tobacco Nicotiana tabaccum L. Thai J Agri Sci 44(1): 33-39.

11. Steel RGD, Torrie JH \& Dickey D (1997). Principles and Procedure of Statistics. A Biometrical Approach 3rd Ed. McGraw Hill Book Co. Inc., New York. pp. 352-358. 
12. Ullah F, Shakur M, Badshah H, Amin M \& Zamin M (2012). Efficacy of Trichogramma chilonis Ishii in comparison with two commonly used insecticides against sugar cane stem borer (Chilo infuscatellus). $\quad$ Pyralidae: Lepidoptera. J Anim Plant Sci 22(2):463-466.

13. Shahid MR, Suhail A, Arif MJ, Gogi MD, Shahzad MA \& Hussain S (2007). Effectiveness of Trichogramma chilonis (ishii)(Hymenoptera:Trichogrammat idae) against sugarcane stem borer (Chilo infuscatellus Snellen)(Lepidoptera:Pyralidae). Pak. Entomol 29(2): 141-146.

14. Selvaraj A (1994). Release of different doses of Trichogramma and its effect on internode borer, yield and quality of sugarcane. Sugar Cane (United Kingdom). 2: 22-23.

15. Farid A, Khan MIN, Khan A, Khattak SU, Alamzeb \& Sattar A (2007). Studies on maize stem borer, Chilo partellus, in Peshawar valley. Pak J Zool 39(2): 127-131

16. Ahmad S, Ashfaq M \& Sahi ST (2012). Potential of parasitoid Trichogramma chilonis (Ishii) (Hymenoptera: Trichogrammatidae) against the sugarcane stem borer, Chilo infuscatellus (Lepidoptera; Pyralidae) under field conditions. Int J Biodivers Conserv 4: 36-38. 